\title{
In Memoriam: Clifford Carlyle Shaw
}

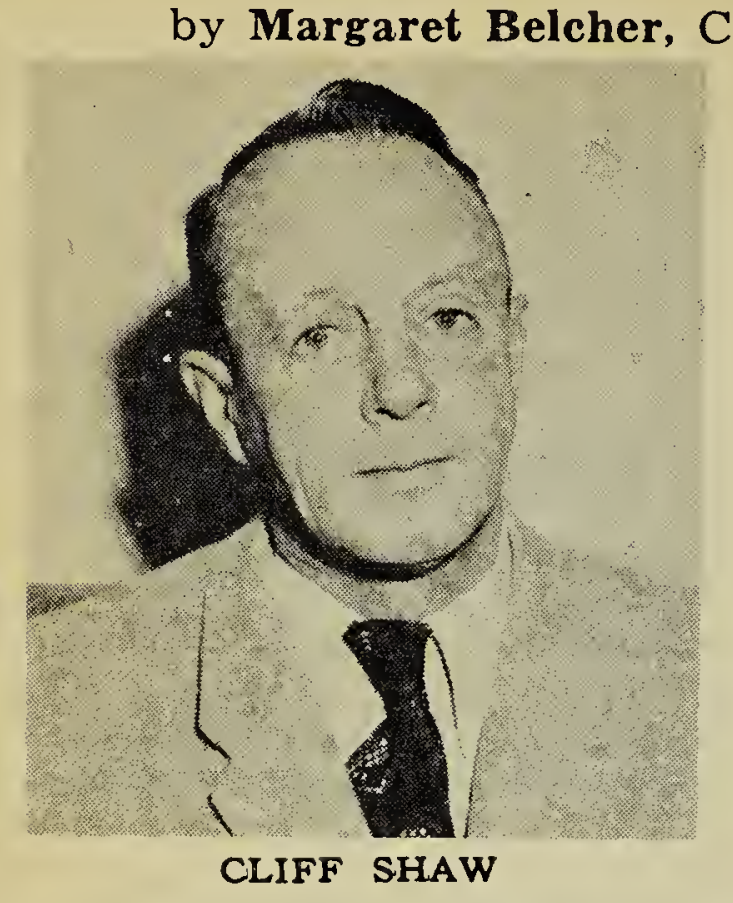

As this issue of the Blue Jay goes to press we sadly record the death of Cliff Shaw in Yorkton. He died in hospital on Monday, July 13 after a heart attack which he took that morning in his office. The funeral was held in St. Andrew's United Church on Wednesday, July 15 and he was buried in the cemetery which, as a member of the town planning committee, he had helped to beautify.

Clifford Carlyle Shaw was born September 13, 1907 at Elgin, Manitoba. His family moved in 1918 to Bulyea, Saskatchewan, where Cliff went to school, later attending Regina College and the Success Business College. Then followed a multiplicity of jobs in the depression years, with two happy summer interludes spent on museum assignments: in 1934 he collected insects at Waskesiu for the British Museum, and in 1936 he spent the summer months with a friend digging up prehistoric animals, hunting Indian artifacts, and so on.

Cliff Shaw joined the staff of the Leader-Post in Regina in 1941 and in 1944 was transferred to Yorkton as manager of the Sifton News Bureau. Through his work with the three newspapers - the Regina LeaderPost, the Saskatoon Star-Phoenix and the Winnipeg Free Press - Cliff Shaw was known to many people on the prairies. Yet few people knew how worthwhile and how varied were the contributions which he made to the life of his community and this prairie country. As his newspaper colleague Harold Long- man, provincial editor of the Regina Leader-Post, observed: "It is traditional in the newspaper world that people who are employed in it get little personal publicity. It is by way of tribute to him that I say that his wide knowledge of many things and his widespread interests would have made him a subject worth writing about had he himself not been a newspaperman."

In addition Cliff Shaw was given to saying very little about himself for he was the most modest of men. Blue Jay readers will know that he was a member of the Manitoba Natural History Society, secretary of the Regina Natural History Society, past president of the Yorkton and Saskatchewan Natural History Societies, and former editor of the Blue Jay (following Mrs. Priestly's death in 1946). Many readers will not know that he was also past president of the Yorkton and Saskatchewan Horticultural Societies, vice-president of the Yorkton Museum Association, member of the Manitoba Museum Association, the Saskatchewan Archaeological Society, the Entomological Society of Canada, and the Coleopterist Society of America. The most complete collection of Saskatchewan beetles (now in the provincial Museum) was made by Cliff Shaw

"Cliff Shaw endeared himself to us in the Saskatchewan Natural History Society by his whimsical sense of humour, his appreciation of all things in nature and his spontaneous friendliness. He had that natural instinct of hospitality (shared by his wife Ruth) that made you feel welcome even when the Shaws themselves were not at home, to wander in Cliff's delightful garden and en. joy his charming collection of native plants. We have found it very hard to take leave of our good friend Cliff.

The community to which he gave so much is establishing a Cliff Shaw memorial fund to provide nature books for the Yorkton Public Library and a cup for annual competition in the Yorkton Horticultural Society. To this fitting tribute will be added the appreciative recognition, on the part of all those who knew Cliff Shaw, of his many talents and his personal integrity. 